\title{
LONG TERM PERFORMANCE OF A SUBMERGED COASTAL CONTROL STRUCTURE: A CASE STUDY OF THE NARROWNECK MULTI-FUNCTIONAL ARTIFICIAL REEF
}

\begin{abstract}
Angus Jackson ${ }^{1}$, Rodger Tomlinson ${ }^{2}$, Bobbie Corbett ${ }^{1}$ and Darrell Strauss ${ }^{2}$
In response to the increasing occurrences of beach erosion along Surfers Paradise and Main Beaches - Gold Coast, Australia, the Northern Gold Coast Beach Protection Strategy [NGCBPS] was developed to widen the beach by 20$30 \mathrm{~m}$ as well as improving surfing conditions as a secondary objective. The strategy, implemented in 1999- 2000, involved large-scale beach nourishment and construction of a submerged breakwater "reef" to act as a control point at Narrowneck. Construction of the reef involved innovative filling and placement methods using very large sand filled geotextile containers coupled with significant advances with regards to design of the geotextile material and containers. In the 11 years since construction, there has been substantial monitoring of the project since its completion in late 2000 including: - video imaging using webcams; hydrographic and beach surveys; aerial and oblique photography; surf and surf safety observations and GPS surfing track plots; and geotextile container condition and stability. This paper presents an update on the performance of the reef over the last four years. In particular, the response of the structure and the shoreline to a series of major storm events in 2009 has been examined. The results have shown that the erosion caused by these major events was accommodated within the wider beach created in 1999. Over the next 2 years there was a gradual recovery in the lee of the reef with a subtle groyne effect resulting in an even larger increase in the width of the updrift beach. A detailed underwater condition survey was also undertaken in 2011, to determine changes in the condition of the geotextile containers. This revealed a number of containers missing or damaged, and that seaward containers were covered by sand. The marine habitat which has been a feature of the reef has been impacted by the increased coverage of sand, but still shows high abundance and biodiversity.
\end{abstract}

Keywords: multi-functional artificial reef; geotextile containers; monitoring; salient

\section{INTRODUCTION}

\section{Background}

The Northern Gold Coast Beach Protection Strategy (Jackson et al., 1997) was developed in response to the ongoing decrease in beach width of the Northern Gold Coast Beaches during the 1990's. The large scale nourishment of $1.5 \mathrm{Mm}^{3}$, which had been placed on the beaches in 1974 following the devastating cyclones of the 1950's and late 1960's, was no longer sufficient to cover the boulder wall at Narrowneck Beach.

Figure 1 shows the exposed boulder wall at Narrowneck following storms in 1996. This section of the boulder wall is some $20 \mathrm{~m}$ seaward of the general seawall alignment resulting in minimal beach widths and potentially hazardous conditions. Widening of the beach by $30-50 \mathrm{~m}$ was proposed to provide a storm buffer for 1:50 year events.

The proposed strategy included the following short term elements:

1. Nourishment: a minimum of $1.5 \mathrm{Mm} 3$ to be pumped from various sources to widen Surfers Paradise beach by $30-50 \mathrm{~m}$. Regular ongoing nourishment of at least $60,000 \mathrm{~m}^{3} / \mathrm{yr}$ is necessary to manage potential down-drift impacts. This quantity can at present be provided from maintenance navigation dredging in the nearby Broadwater estuary and sand excavations from building sites. Back-passing from the Seaway bypass system is another potential source.

2. Coastal Control Point: the control point is to be an artificial submerged (low crested) reef breakwater designed to stabilize the nourishment and provide better and more consistent surfing conditions. The reef should be constructed of mega- sand filled containers designed and fabricated for the project to minimize the hazard to surfers, reduce costs and reduce construction impacts.

3. Pipeline/Boosters: a permanent buried pipeline is required from the Spit to Narrowneck to facilitate regular nourishment to the control structure to improve the beaches down-drift.

4. Management Policies: ongoing nourishment is required and operational procedures will need to be developed. Present policies should be continued to ensure completion of an adequate and continuous seawall and continued supply of additional sand from building sites to the beaches.”

Further investigations by Carley et al. (1998), GCCM and ICM (1998) confirmed that a 30m widening would "provide protection for a single storm event of greater severity than 100yr ARI and adequate buffer for multiple storm events of similar severity to those of 1967”. To achieve the necessary $30 \mathrm{~m}$ minimum beach widening, the volume of sand required was calculated to be $1.3 \mathrm{Mm}^{3}$ (Tomlinson et al., 2007).

\footnotetext{
${ }^{1}$ International Coastal Management Pty Ltd, PO Box 306. Main Beach, Queensland. 4216, Australia

${ }^{2}$ Griffith Centre for Coastal Management, Gold Coast Campus, Griffith University, 4222, Queensland, Australia
} 

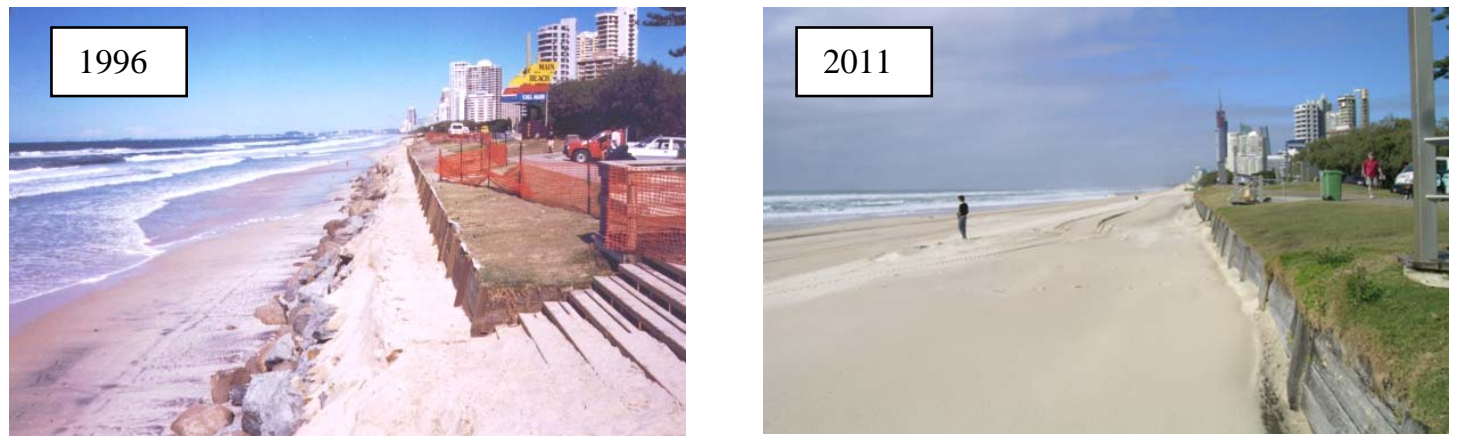

Figure 1. Narrowneck Beach, looking south

An allowance for ongoing nourishment to the north of the control structure to compensate for accretion of the beach to the south and a sea level rise component (initially totalling 60,000-80,000 $\mathrm{m}^{3} / \mathrm{yr}$ and decreasing over time) was included in the strategy however has yet to be implemented. Sources of these nourishment volumes were identified as available sand from building sites and from channel maintenance dredging in the Broadwater. The proposed backpassing facility has also not been implemented however further studies have since been undertaken (e.g. Patterson, 2007), and are continuing.

A total of $1.3 \mathrm{Mm}^{3}$ of nourishment was applied between February 1999 and June 2000, primarily obtained from dredging wider and deeper navigation channels in the Broadwater with some from building sites. The artificial reef was constructed between August 1999 and December 2000. The artificial reef was constructed between August 1999 and December 2000. Figure 1 shows the visible beach at Narrowneck on $24^{\text {th }}$ August 2011.

The complexity of the construction process in the surf zone and on the highly variable and mobile seabed in the surf zone is noted below and highlights the need for continued monitoring and maintenance of the beach and reef structure at Narrowneck.

\footnotetext{
"The nourishment and large storms prior to reef construction had created a very large storm bar (over $1 \mathrm{~m}$ high over the back half of the reef). The bar would migrate shoreward with milder weather. As dredging to potential maximum scour depth, or a scour mattress, were not viable economic options, and as the construction materials allow for easy top-up, a sequenced construction schedule [at reduced cost] with top-up after initial settlement (as the large storm bar migrated shoreward) was undertaken. As recommended, regular maintenance has been carried out.” - Tomlinson et al. (2007).
}

\section{Monitoring Program}

Due to the innovative nature of the reef breakwater and construction method a long term monitoring program was established at the time of construction. The overall performance of the reef has been presented previously by Jackson et al. (2003), Jackson et al. (2005), Jackson, Reichelt et al. (2005), and Jackson et al. (2007). In addition there have been regular six-monthly reports on the impact of the reef on the adjacent shoreline, for example: Blacka et al (2007) and Strauss et al (2012).

Data collection undertaken includes:

- Dive inspections, including underwater imagery to examine the condition of the structure, identify damaged or missing containers and report on the development of marine ecology

- Aerial photographic inventory of the artificial reef

- Bathymetric survey and contour maps

- $\quad$ Side scanning images

- Land and aerial oblique photography.

- $\quad$ Surf parameter observations \& testing.

\section{REEF INTEGRITY}

Several dive inspections have been undertaken since construction in order to evaluate the condition of the reef structure. The purpose of these inspections in the early years after construction was primarily to check on the condition of the geotextile, the developing reef ecology and evidence of structural failure. The recent inspections have focused on locating damaged or missing containers and providing a photographic record of ecological changes.

\section{Reef design}

The design criteria for the Narrowneck artificial reef were (Jackson et al, 1997):-

- $\quad$ to act as a coastal control point to stabilize the nourished beaches to the south 
- after the initial nourishment of $1.3 \mathrm{Mm}^{3}$ the maximum annual trapping capacity be $100,000 \mathrm{~m}^{3} / \mathrm{yr}$ as this quantity of suitable sand can be provided from outside the active system

- the reef be shaped to provide improved surfing conditions

- the reef be constructed so as not to be hazardous to surfers

To achieve these objectives there has been a progressive evolution of the reef shape since the major construction phase was completed in 2000. The final revised design (2004) is shown in Figure 2.
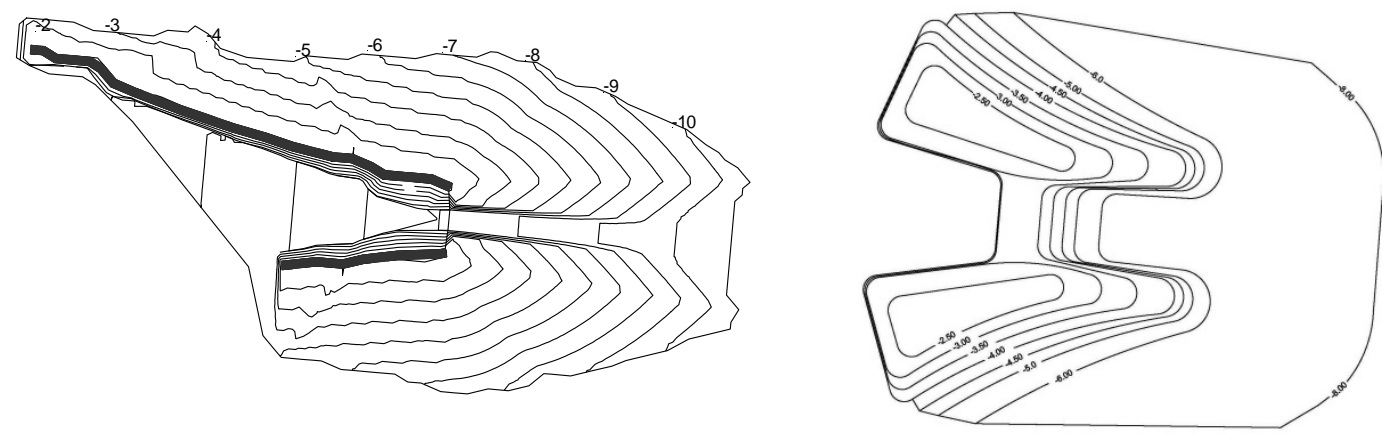

Figure 2. Reef Levels - Original and Revised Design

Construction was carried out using mega sand filled containers designed to fit in the hopper of the contractors split hull hopper dredge. Rather than the usual practice of sewing the containers closed on the dredger, they were prefabricated to the required size and filled from the dredge pump outlet filling and discharging tail water through trunks that were sealed above water to avoid the need for underwater diving work. Considerable development of high durability geotextile, seaming methods and inlet / outlet trunk closing methods were developed. Accuracy of placement was sub $1 \mathrm{~m}$.

\section{Previous Maintenance}

Overall, some 450 containers have been placed to form the reef since 1999 (Figure 3). Of those, 42 have been placed in three maintenance campaigns as shown in Figure 4.

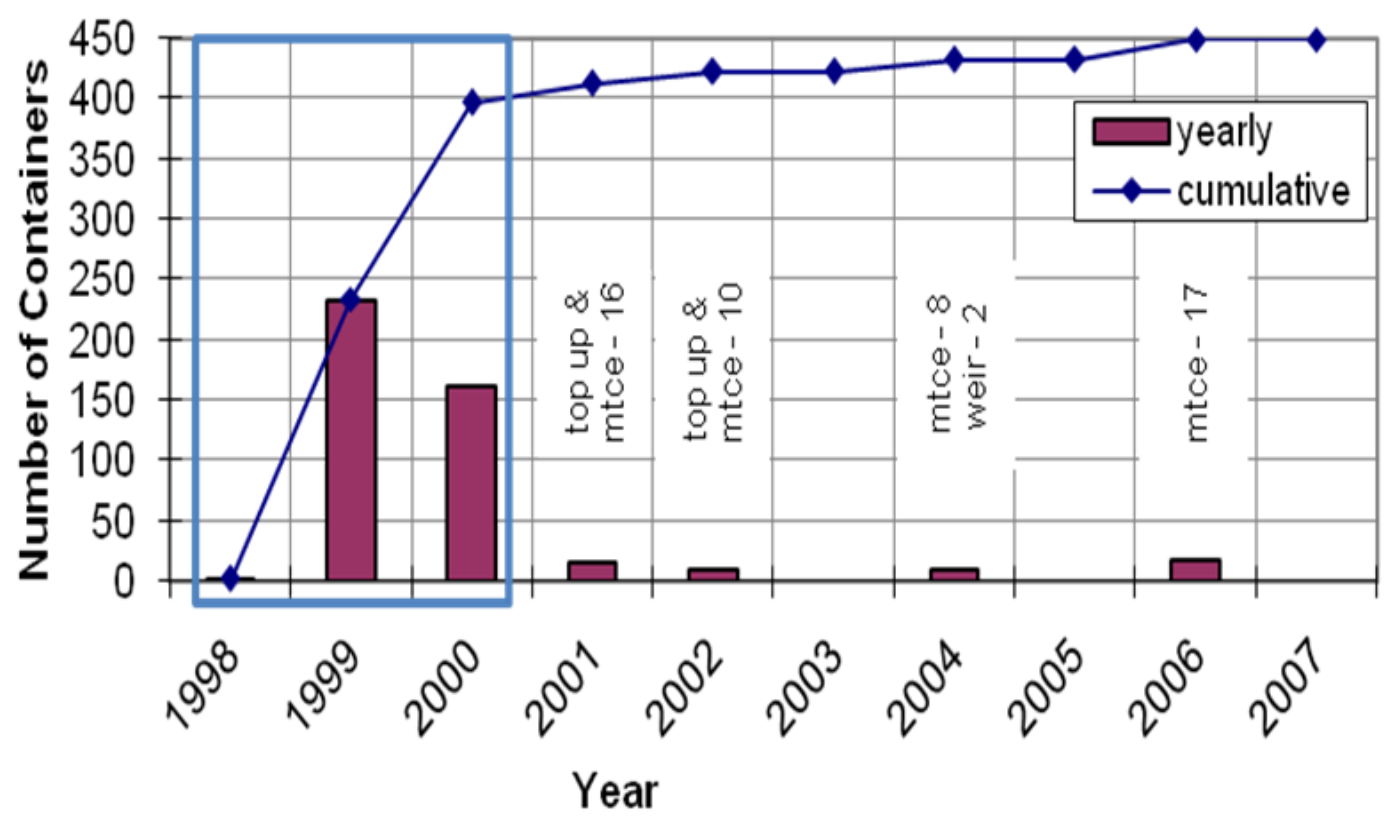

Figure 3. Container placement schedule

A significant modification was made to the original design in 2004 with the establishment of a submerged weir between the two arms of the reef as well flared wings. The reason for the introduction of a weir was to mitigate against wave penetration through the channel which was allowing the creation of a double salient at times (the central channel was originally included in the design during modelling but with lowered crest, the predicted high currents did not occur so the channel was not as necessary 
than originally envisaged). The flared wings were introduced primarily to improve the effectiveness of the reef, and improve surf by improving the link from the reef break to the adjacent shore break.

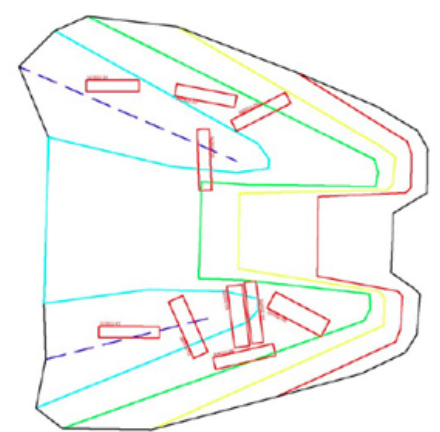

$2002 / 2003$

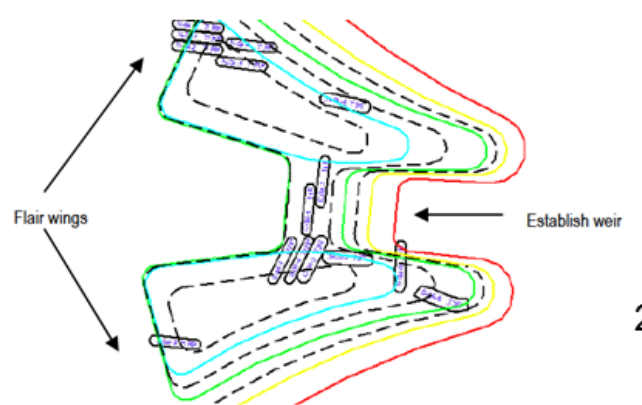

2004

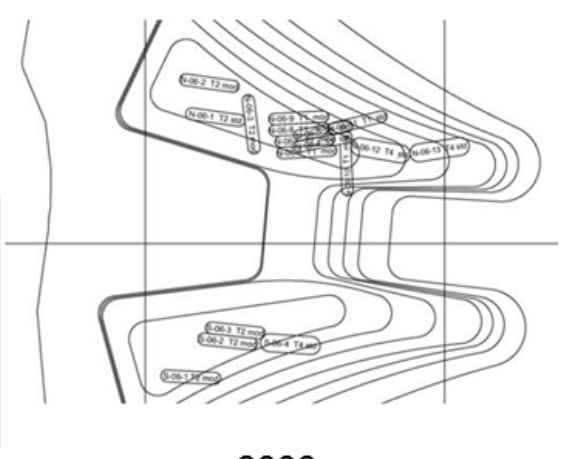

2006

Figure 4. Placement of Containers for Reef Maintenance

\section{Bathymetric Survey}

As part of the recent update of the performance of the reef, a survey of the Narrowneck reef was undertaken by the Gold Coast City Council on $9^{\text {th }}$ June 2011 (Figure 5) and an isopach comparing this survey with another survey undertaken in 2008. It is noted that survey of this type of structure is very useful but needs interpretation and verification since individual containers are unusual in shape and not always well represented by the survey interpolation.
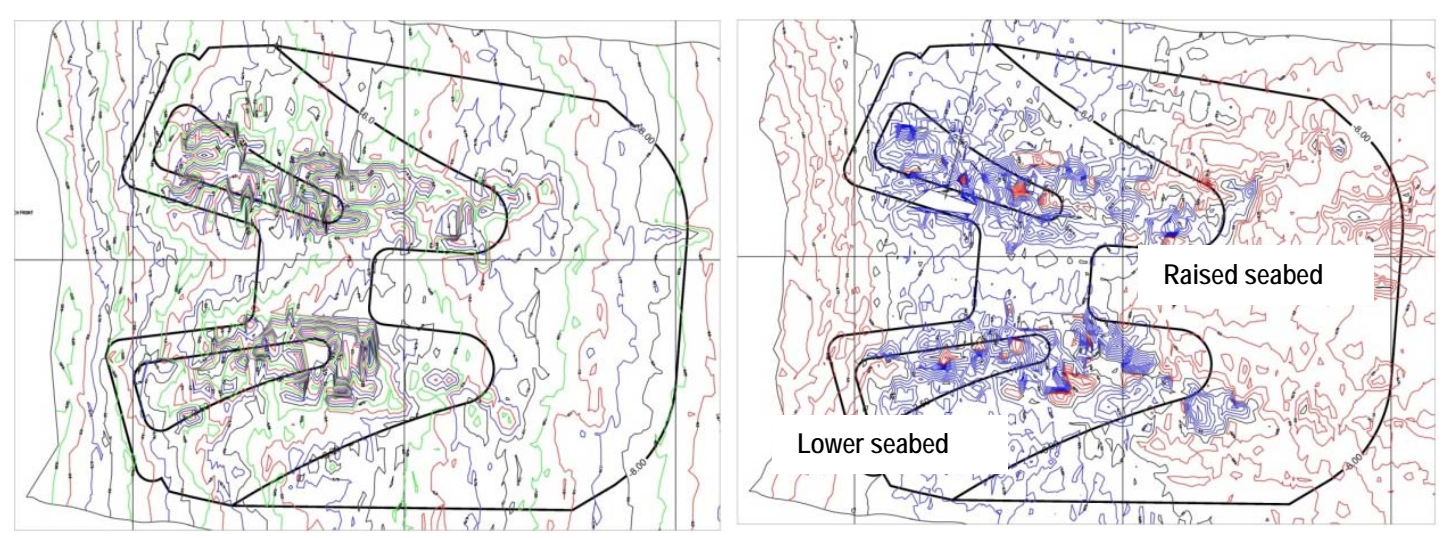

Figure 5.a) Reef Bathymetry (9/6/11), b) Isopach showing changes to surveyed levels between 2008 \& 2011

An interpretation of the survey of critical crest areas showed that there are particular areas where there would be sufficient height to place a mega-container and areas where the isopach indicates a container has been lost since 2008. This has been overlaid with as-constructed survey of containers placed as part of previous maintenance campaigns. This indicates that:

- Maintenance of the structure is required as there are critical areas below design levels

- $\quad$ Since 2008 (3 years), the isopach indicates some 10 containers have been compromised

- Raising of seabed levels on outer reef since 2008 appears to have resulted in burial of seaward containers 


\section{Aerial Images}

Aerial images of Narrowneck reef during calm conditions are occasionally clear enough to clearly distinguish individual bags (Figure 6) and can be very useful for reviewing the condition of the reef prior to direct inspection. Overlay of the most recent (July 2011) aerial photo with as-constructed survey of containers placed as part of previous maintenance campaigns (Figure 7) indicates that:

- Raising of the seabed levels on the outer reef has resulted in extensive burial of seaward containers. It does not appear that these containers are missing, although their condition is unknown and it is expected that there would be some damage in these outer areas.

- Partial burial of containers used for design modification indicates that a change to crest levels likely reflects settlement due to lack of foundation containers rather than damage or loss of the containers themselves.
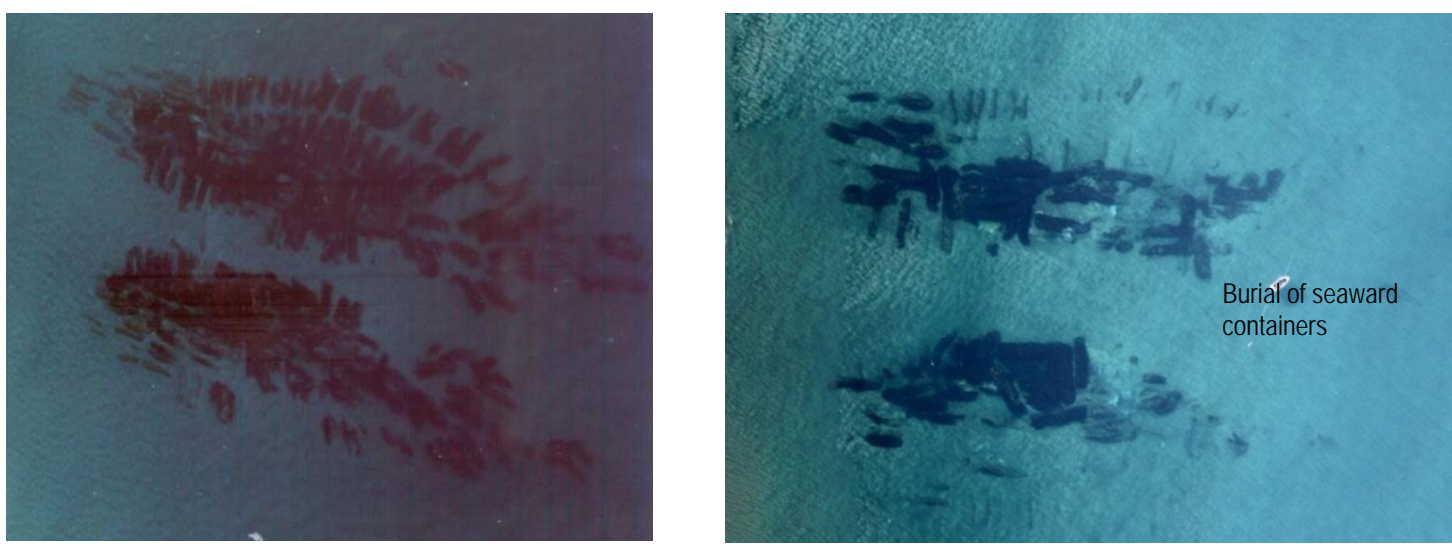

Figure 6. Aerial photographs taken in 2004 and 2011

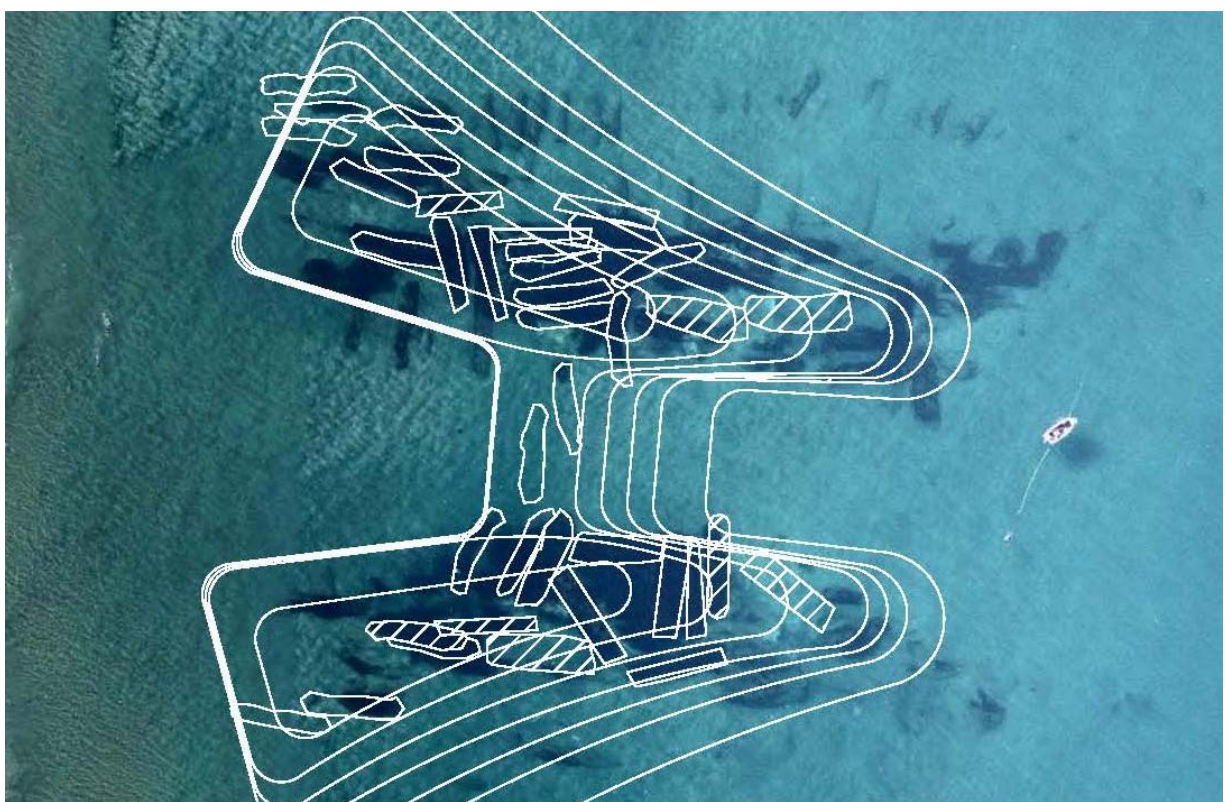

Figure 7. Overlay of July 2011 Aerial Photo with containers placed during maintenance campaigns (ICM)

\section{Inspection}

On site verification of the survey and aerial information is necessary. As such, multiple underwater inspections have been undertaken [in so far as this was possible given the extent of the growth on the containers and the burial of large sections of reef].

The nearshore seabed is highly variable and a large proportion of the structure is presently buried by a large storm bar and could not be inspected. Of those containers which could be inspected, the majority appear to be in good condition and have retained their shape well. Despite being some 11 years since placement of many of the containers, visual inspection revealed: 
- $\quad$ Raising of the seabed levels on outer reef has resulted in extensive burial of seaward containers. It does not appear that these containers are missing, although their condition is unknown and it is expected that there would be some damage due to anchors in these outer areas as it is a popular fishing location.

- No evidence of a general deterioration or wearing of the standard (ELCOMax 1200R) or composite (ELCOMax 1209RP) geotextile on intact containers

- At least one container with the unsuccessful trial polyurethane coating is still present and in good condition, although several of these have failed (Figure 8). This coated geotextile was discontinued usage during initial construction as it made the containers more rigid and stress cracking was observed relatively quickly after placement. Progressive failure of these trial containers was expected.

- $\quad$ No evidence of diminished seam integrity, i.e. splitting or fraying. It was noted that seams of failed containers also generally remained in good condition.

- No evidence of failure of the "complex" closures developed during this project to cope with the very large wave forces acting on the containers.

It is noted that the nominated guaranteed lifetime of the standard $1200 \mathrm{R}$ geotextile is 15 years and the reinforced 1209 geotextile is 25 years, although this is primarily driven by the UV exposure and is expected to be significantly lengthened by the presence of marine growth.

For containers placed as part of the original construction, there is not adequate as-constructed survey of individual containers for effective container identification. This information is available for the containers placed as part of maintenance campaigns and specific inspections of these containers were undertaken. Of the 42 containers:

- 26 containers were inspected and found in good condition

- 6 containers were substantially buried

- 8 containers were either damaged or missing entirely

- 2 containers were known to have failed previously

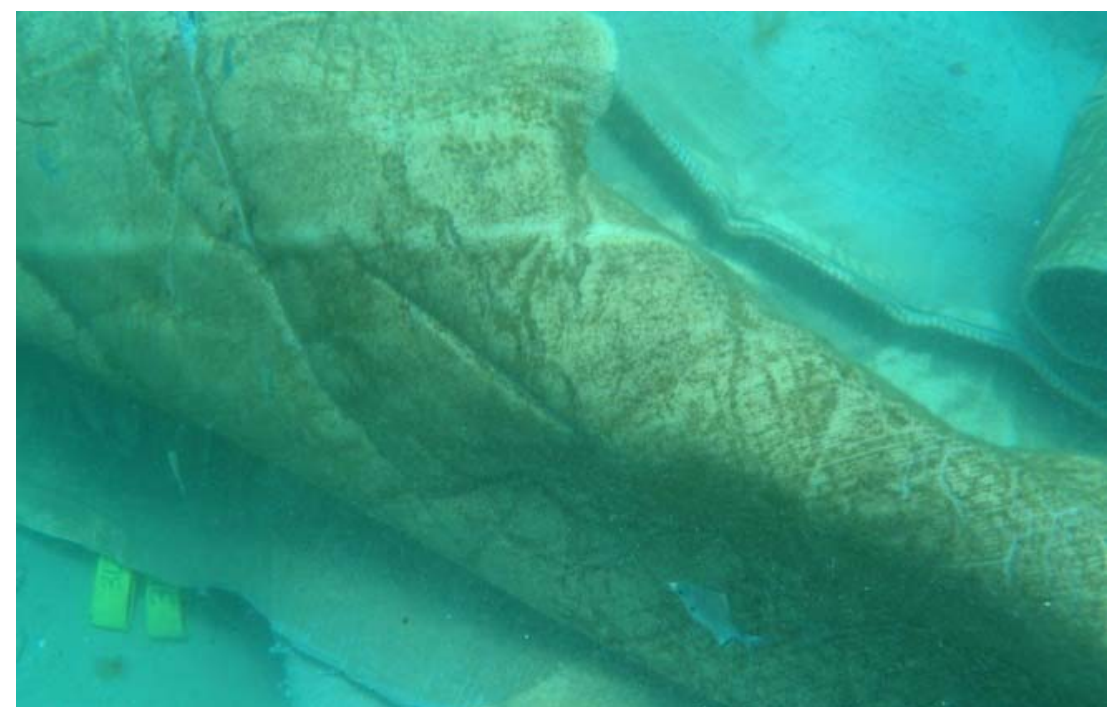

Figure 8. Failed container with polyurethane coating

\section{Settlement}

In 2004 two containers were placed on the existing sandy seabed to create the weir across the central channel between the northern and southern reefs. As such, there was no attempt to provide a foundation to support the containers during periods where the seabed was eroded and this resulted in lowering the container to scour level. This was expected and as dredging to possible scour level was not as cost effective as the strategy of allowing settlement and topping up, initial placement heights were approximately $0.5 \mathrm{~m}$ above design levels to provide some initial compensation. Since placement, these containers have experienced lowering of up to $2 \mathrm{~m}$, resulting in present levels some $1.5 \mathrm{~m}$ below design. Containers are predominantly buried at present (Figure 6).

Two containers were also placed to provide a widened, more flared crest. These containers have also experienced settlement, although this is limited to $1-1.5 \mathrm{~m}$ [and as a result present levels are 
within $1 \mathrm{~m}$ of design levels]. Again, containers are predominantly buried during seabed conditions at present (Figure 6).

Four containers showed significantly lowered levels on the isopach survey (Figure 5) although visual inspection indicates that the crest containers are in good condition and it appears likely that the slumping is the result of failure of lower containers (Figure 9).

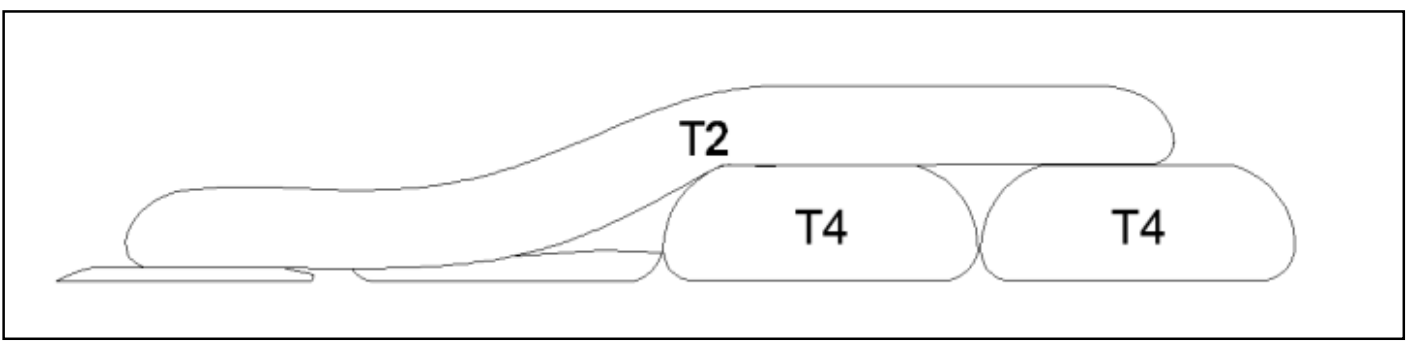

Figure 9. Conceptual sketch showing slumping

\section{Damaged Containers}

Visual identification and inspection of containers placed as part of maintenance works was undertaken and damaged or missing containers were identified as shown in Table 1.

During inspections it is often difficult to definitively identify the cause of damage because the initial cause of failure is masked by the damage suffered during cyclic flapping and deflation of the container. After the container is fully deflated, weather events can often result in complete removal of the remaining material, leaving no evidence as to potential cause of failure. The reef is a very popular fishing area and there has previously been clear evidence of instances where damage has been the result of:

- Propeller damage

- Anchor damage

- Vandalism and spears from spear guns

\begin{tabular}{|c|c|c|c|c|}
\hline $\begin{array}{l}\text { Date } \\
\text { Placed }\end{array}$ & Type ** & Size & Status in 2011 & Comments \\
\hline 2002 & $\begin{array}{l}1 / 2 \text { Standard } \\
1 / 2 \text { Composite }\end{array}$ & T2 & $\begin{array}{l}\text { Container not } \\
\text { evident }\end{array}$ & Previous anchor damage repaired on 9/11/2002 \\
\hline 2002 & $\begin{array}{l}1 / 2 \text { Standard } \\
1 / 2 \text { Composite }\end{array}$ & T1 & $\begin{array}{l}\text { Container not } \\
\text { evident. }\end{array}$ & \\
\hline 2002 & Standard & T4 & $\begin{array}{l}\text { Container not } \\
\text { evident. }\end{array}$ & \\
\hline 2006 & Standard & T4 & $\begin{array}{l}\text { Failed } \\
\text { Container. }\end{array}$ & \\
\hline 2006 & Standard & T4 & $\begin{array}{l}\text { Container not } \\
\text { evident. }\end{array}$ & \\
\hline 2006 & $\begin{array}{l}1 / 2 \text { Standard } \\
1 / 2 \text { Composite }\end{array}$ & $\mathrm{T} 2$ & $\begin{array}{l}\text { Container not } \\
\text { evident. }\end{array}$ & $\begin{array}{l}\text { High container vulnerable to damage. } \\
\text { Trunk cover damage repaired in April } 2007\end{array}$ \\
\hline 2006 & Standard & T4 & $\begin{array}{l}\text { Container not } \\
\text { evident. }\end{array}$ & \\
\hline 2006 & Standard & $\mathrm{T} 2$ & $\begin{array}{l}\text { Failed } \\
\text { Container. }\end{array}$ & $\begin{array}{l}\text { Ear evident upon placement. } \\
\text { Repaired trunk cover May } 2006 .\end{array}$ \\
\hline
\end{tabular}

** Standard is ELCOMax 1200R ; Composite is ELCOMax 1209RP

During the 2011 inspection, one container was almost fully deflated and showed clear evidence of propeller damage (Figure 10). The slumping on the north reef due to damage of base containers would indicate potential damage due to anchors. As a result, it seems clear that damage to the structure as a result of vessels is ongoing.

The fact that the majority of the damaged containers were of the standard 1200R geotextile would indicate that the reinforced 1209RP geotextile (developed specifically for this project) is in fact proving to be more robust and anchor resistant. Continued usage would be expected to reduce ongoing maintenance requirements.

Where there was no indication of previous damage, 4 of the 5 containers were standard T4 containers. Given previous observations indicating that these size containers tended not to be as well 
filled as smaller containers and tended to develop 'ears', it is possible that these containers may be more vulnerable to flapping during large events. It is noted, however, that these containers are located in deeper water, which also makes them more vulnerable to anchor damage.

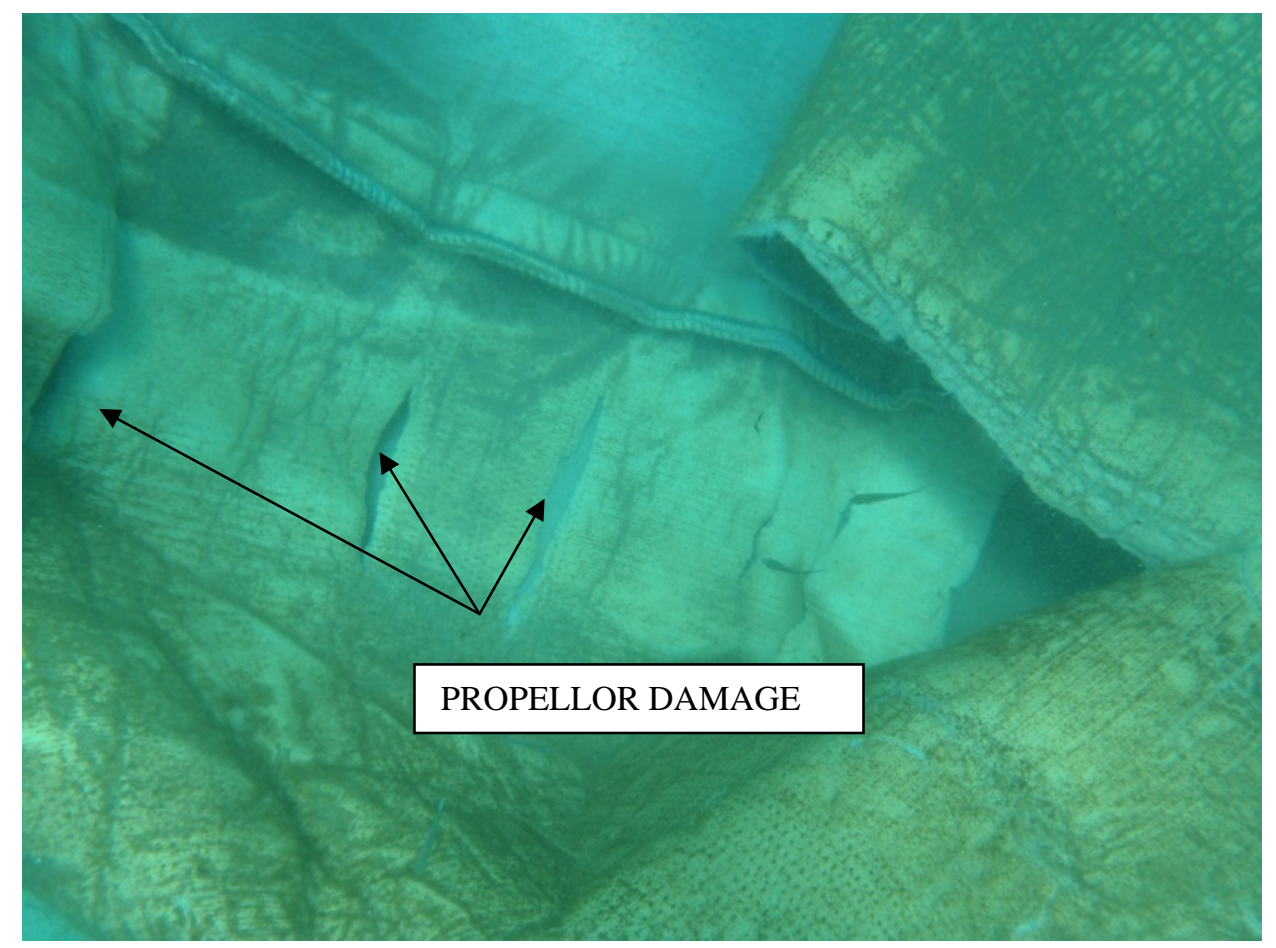

Figure 10. Container with evidence of propeller damage

\section{ECOLOGICAL ASPECTS}

A full ecological inventory was reported on in Jackson et al. (2007). For the current update, dive inspections were carried out to evaluate and photograph the reef to assess any qualitative ecological changes.

\section{Observations}

During the dive inspections, observations were also made of the marine species present on the reef. While this is not a comprehensive assessment, it provides a qualitative indication of changes. Critical changes identified during 2011 monitoring include:

- Diversity of shallow containers has increased. During previous monitoring these containers were dominated by macro algae / sea grasses. The more diverse growth was limited to the deeper sections of the reef. Crest layer containers now support a wider range of species (Figure 11), including kelp and sponges as well as a range of brown algae and red algae.

- Some containers show evidence of growth in the early stages of development and it is expected that these containers have recently been exposed after a period of burial

- Growth on deep containers has likely been eliminated due to extended burial beneath the welldeveloped storm bar. It is expected that these regions will develop quickly as they become exposed once more.

- Containers placed in 2005/06 are diversifying at a much greater rate, likely due to increased recruitment of marine life from existing reef.

- Areas of high diversity remain concentrated on vertical faces and areas where the reef's structural complexity is high.

- Pelagic fish remain dominated by yellowtail scad, although the population of these pelagic species is likely variable.

- Major species, including turtles, wobbegongs and stingray are still resident on the reef. 



Figure 11. Marine Species Present on the Reef

\section{BEACH WIDTH}

The exposed boulder wall (Figure 1) that was visible prior to the nourishment and reef construction has remained completely covered despite the occurrence of several large storms and a significantly wider beach has been evident since 1996. Wave conditions experienced in 2009 were considered to be the stormiest for more than 20 years. Seven storms with significant wave height exceeding $3 \mathrm{~m}$ impacted the coast between February and May 2009 causing significant erosion (Figure 12). The last and largest was caused by an "East Coast Low" which persisted from 19-25 May. The storm recorded a peak significant wave height of $6.2 \mathrm{~m}$ and a maximum wave height of $10.6 \mathrm{~m}$. Peak periods reached $14 \mathrm{~s}$ and wave direction was predominantly easterly (shore-normal to the coast) (Figure 11). The combined storm surge and high energy waves, which persisted above $2 \mathrm{~m}$ from May 19th to May 25th (Figure 13), resulted in widespread erosion of beaches. The maximum significant wave height of $6.1 \mathrm{~m}$ corresponds to a 1:10 year event according to the extreme wave analysis of Allen and Callaghan (2000) (Table 2).

The April to October 2009 six month average shoreline position decreased by $20 \mathrm{~m}$ in the vicinity of Narrowneck Reef with respect to the previous six month period, primarily in response to the May 2009 storm event (Splinter et al, 2009). The average beach width along the CoastalCOMS monitored area of the northern beaches at the end of May 2009 and for the six months to October 2009 was 60m (Figure 14).

The latest analysis of beach width at Narrowneck derived from the CoastalCOMS monitoring system reveals a monthly average beach width varying from 50 to $100 \mathrm{~m}$ along the section of coastline covered by the analysis shown in Figure 15. Much of this increase may be due to onshore movement of nourishment sand placed offshore. This sand was dredged from the Gold Coast Seaway and has provided nourishment to the active profile depths of around 6-9m offshore of Surfers Paradise. The nourishment volume was approximately $170,000 \mathrm{~m}^{3}$.

\section{Impact of reef on shoreline}

The analysis of beach width trends conducted in 2007 (Blacka et al, 2007) suggested that the beach had achieved an equilibrium state following the completion of nourishment in mid-2000. Seasonal variability of $\sim 40 \mathrm{~m}$ in shoreline position is consistent with the impact of the May 2009 storm event and recovery. The beach width from Narrowneck to Surfers Paradise was fairly uniform at around 50-60m in May 2009 whereas the latest monitoring (October 2011, Figure 15) displays beach width of around 
$70 \mathrm{~m}$ at Narrowneck increasing to $100 \mathrm{~m}$ at Surfers Paradise. This is indicative of the reef providing a minor groyne effect and acting to widen the beach updrift as per the original design. However, the absence of a long term salient on the shoreline suggests that for some wave conditions there is sufficient long shore transport occurring shoreward of the reef to inhibit the formation a permanent salient.

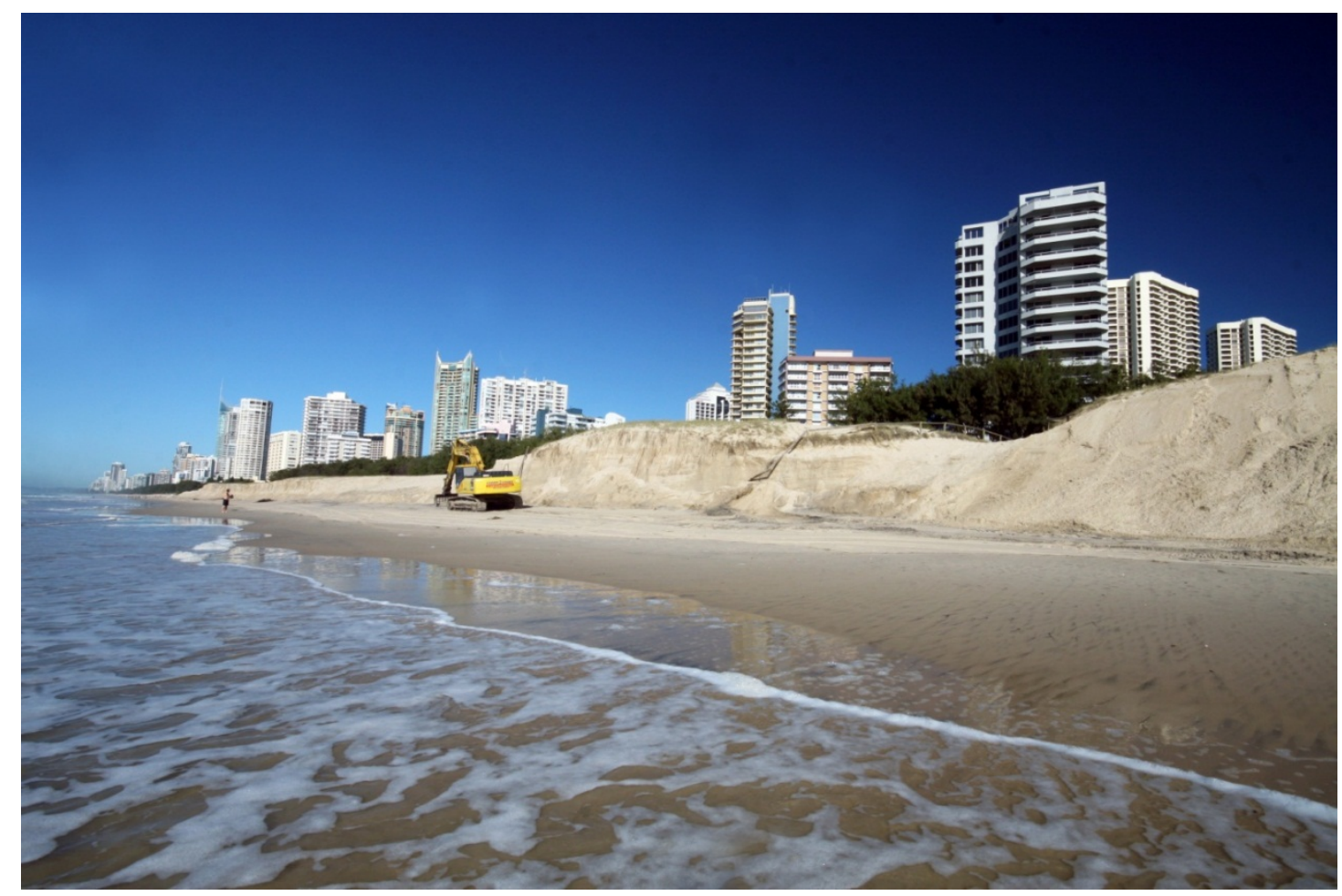

Figure 12. Narrowneck beach looking south - June 2, 2009

Wave Height (Gold Coast Wave Buoy)

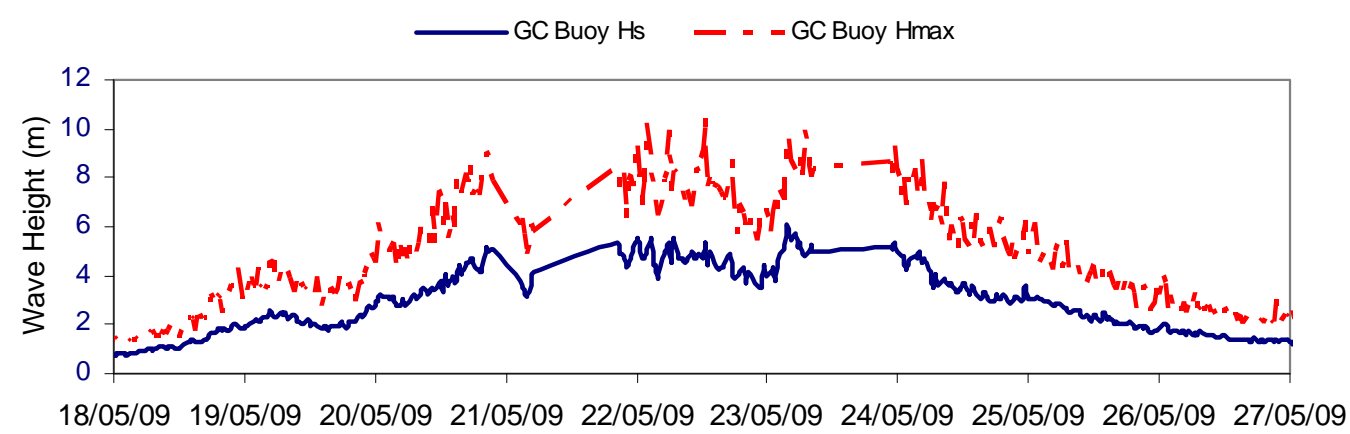

Figure 13. Wave height measured at the Gold Coast Seaway wave rider buoy (DERM).

\begin{tabular}{|c|c|c|c|}
\hline $\begin{array}{l}\text { Average return } \\
\text { Interval (year) }\end{array}$ & $\begin{array}{c}\text { East Coast Lows } \\
\text { Hsig }(\mathrm{m})\end{array}$ & $\begin{array}{c}\text { Tropical cyclones } \\
\text { Hsig (m) }\end{array}$ & $\begin{array}{c}\text { Combined } \\
\text { Hsig(m) }\end{array}$ \\
\hline 2 & 4.85 & 3.89 & 5.02 \\
\hline 5 & 5.67 & 4.60 & 5.83 \\
\hline 10 & 6.10 & 5.20 & 6.29 \\
\hline 20 & 6.47 & 5.83 & 6.71 \\
\hline 50 & 6.90 & 6.7 & 7.28 \\
\hline 100 & 7.2 & 3 & 7.75 \\
\hline
\end{tabular}



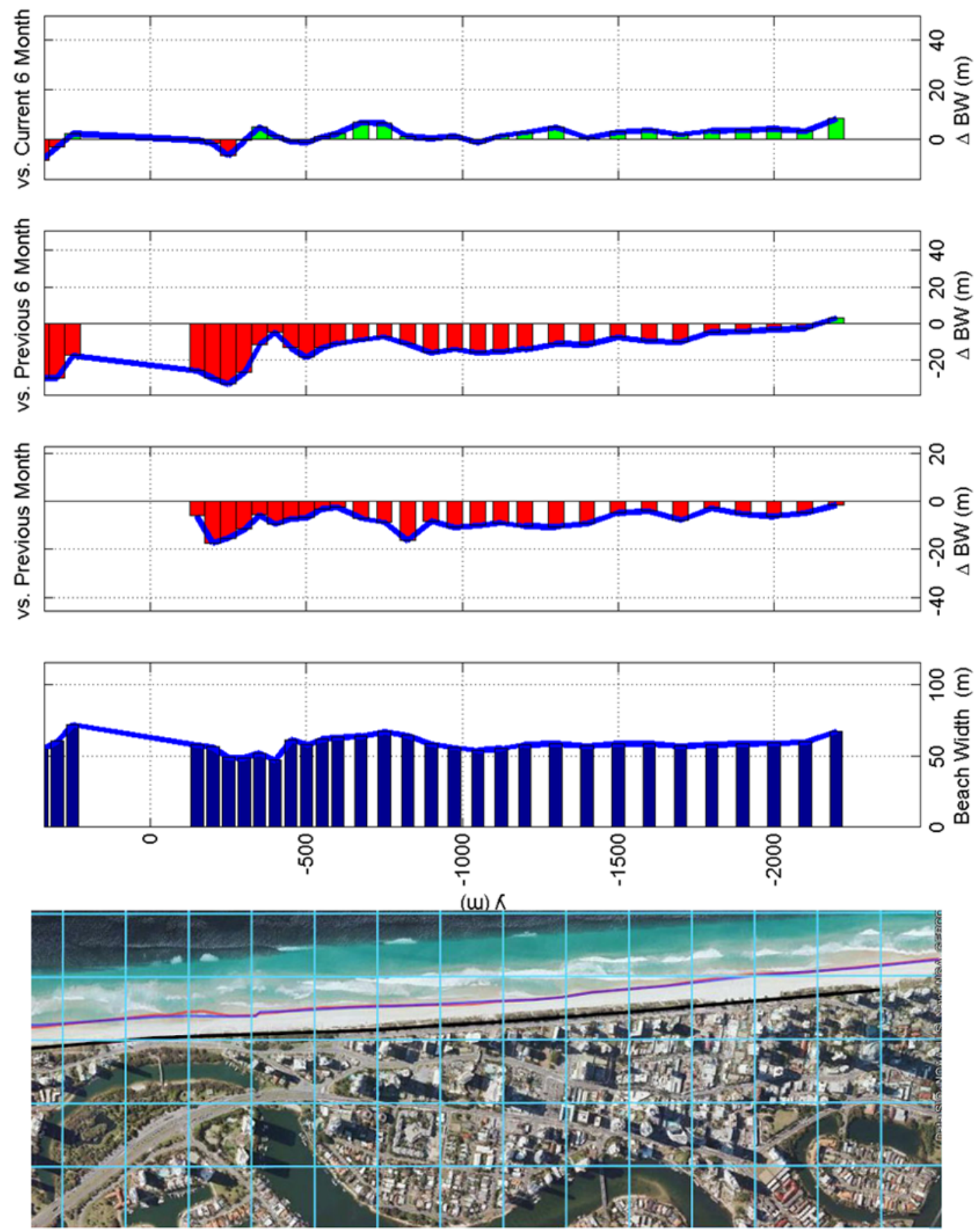

Figure 14. Northern Gold Coast beach width (400 to $-2200 \mathrm{~m}$ ), May 2009 (from top to bottom): (a) Beach width relative to current 6 month mean, (b) Beach width relative to previous 6 month mean (c) Change in beach width from previous month, (d) Mean beach width, (e) Monthly average shoreline position (CoastalCOMS).

Furthermore, the anticipated need for maintenance nourishment of the shoreline north of the reef (downdrift) due to groyne effects has not yet been required. A distinct salient in the lee of the reef is not continuously present but is a recurring feature which can be clearly identified in time exposure images such as in Figure 16.

\section{Other Observations}

The reef structure has generally produced a salient as predicted by physical and numerical modelling; however the location of the salient is offset by $100 \mathrm{~m}$ from the centreline of the reef. The continuing evolution of a marine habitat on the reef has resulted in it becoming a very popular fishing and, to a lesser extent, dive location. 

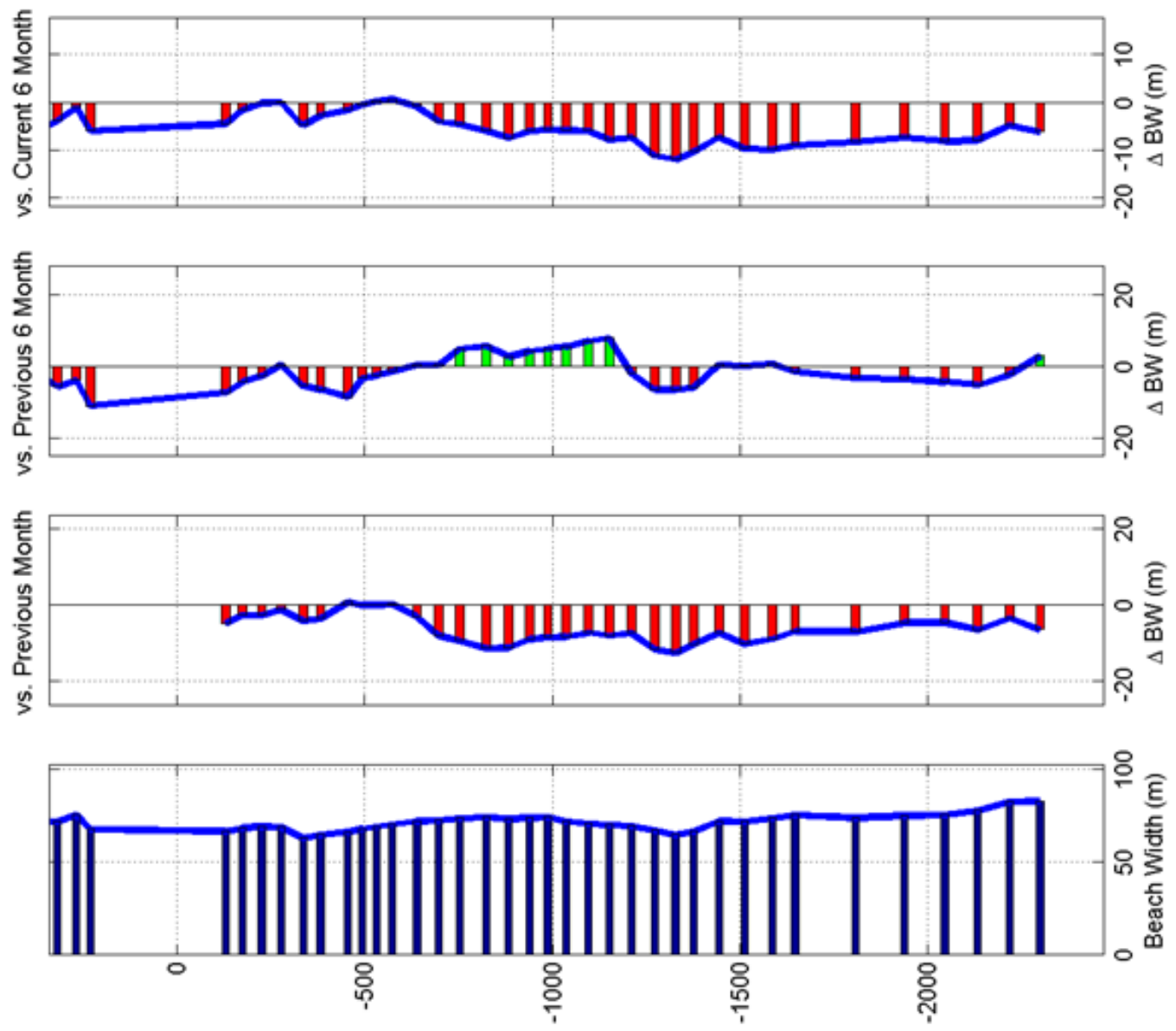

(w) $K$

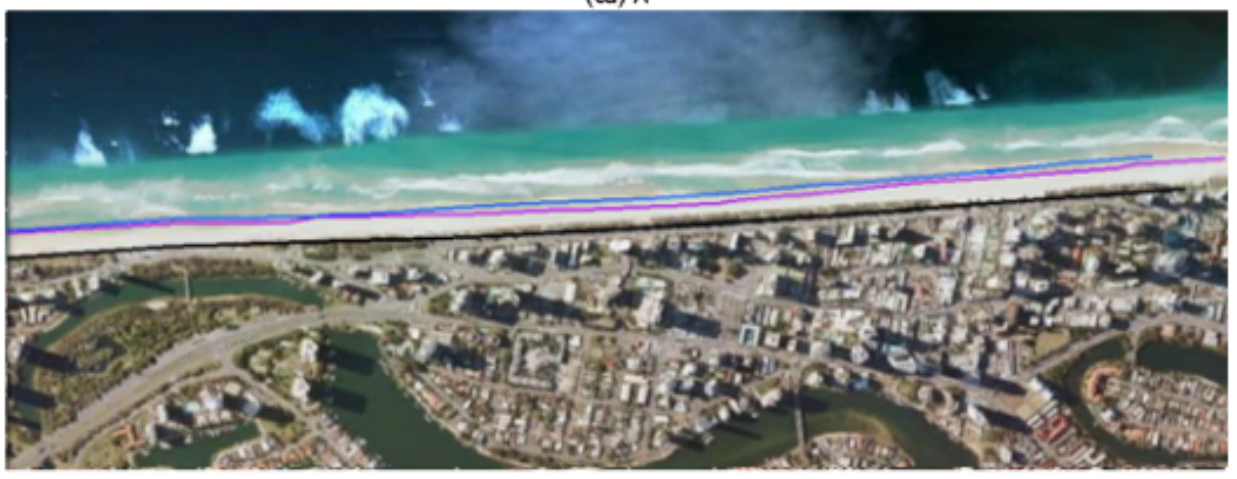

Figure 15. Northern Gold Coast beach width (400 to -2200m), October 2011 (from top to bottom): (a) Beach width relative to current 6 month mean, (b) Beach width relative to previous 6 month mean (c) Change in beach width from previous month, (d) Mean beach width, (e) Monthly average shoreline position (CoastalCOMS).

The reef structure has generally produced a salient as predicted by physical and numerical modelling, however the location of the salient is offset by $100 \mathrm{~m}$ from the centreline of the reef. The continuing evolution of a marine habitat on the reef has resulted in it becoming a very popular fishing and, to a lesser extent, dive location.

In terms of detailed aspects of the container structure, the trunk covers have proven successful in avoiding vandalism to the inlet and outlets closures. However, anchors from vessels over about $8 \mathrm{~m}$ length have caused considerable damage. A "no anchoring zone" was implemented but this was not maintained. As a result major maintenance has been required as set up above, with further maintenance placement being required. 
In terms of safety and recreational usage, no injuries have been reported on the reef. The crest height of about $1-1.5 \mathrm{~m}$ below low tide has proven to be suitable for prevention of injuries but has not optimised the surf quality (Corbett et al 2005).
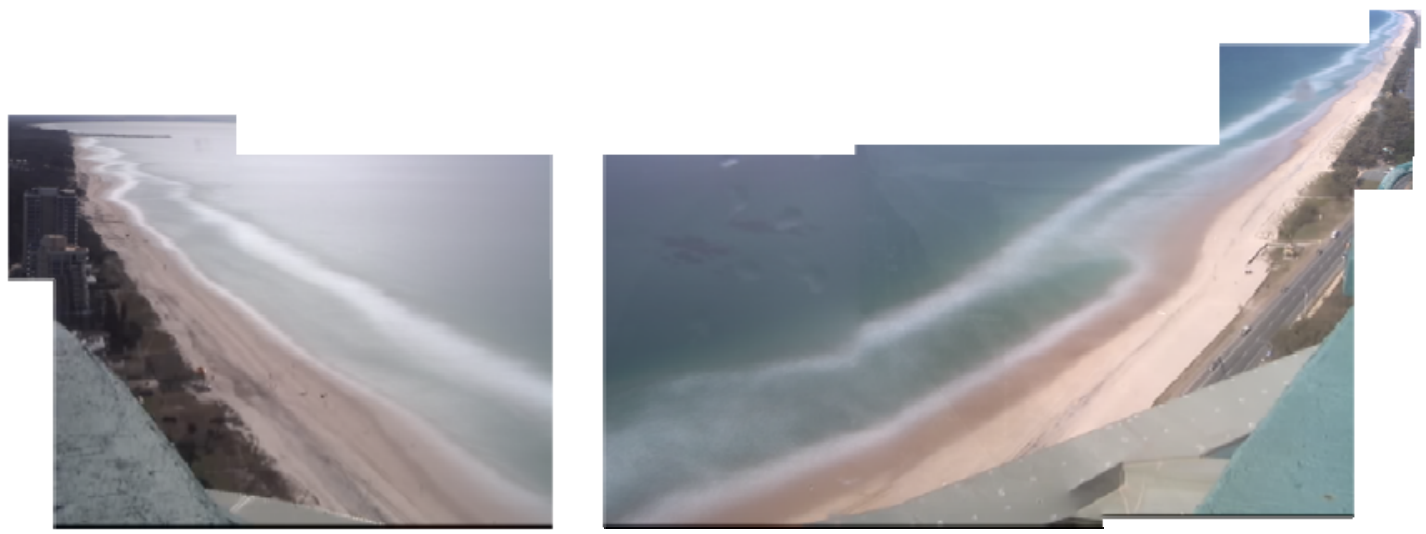

Figure 16. Salient in lee of Narrowneck Reef on May $20^{\text {th }}, 2010$

\section{ACKNOWLEDGEMENTS}

The work presented here was undertaken as part of the Gold Coast Shoreline Management Plan Implementation funded by the Gold Coast City Council. Shoreline position analysis was undertaken in partnership with CoastalCOMS Pty Ltd under contract to the Gold Coast City Council.

\section{REFERENCES}

Allen, M. and Callaghan, J. (2000) Extreme wave conditions for the South East Queensland coastal region. Environment Technical Report 32. Brisbane: Environmental Protection Agency

Blacka, M.J., Anderson, D.J. and Cunningham, I.L., (2007). Analysis of Shoreline Variability, Seasonality and Erosion / Accretion Trends: February 2007 - July 2007. Report 16: Northern Gold Coast Coastal Imaging System. Water Research Laboratory Technical Report 2007/34, UNSW.

Carley, J.T. Couriel, E.D. \& Cox D.R., (1998). Numerical Modelling Sand Nourishment Profiles / Quantities and Beach Erosion Due to Storms and Sea Level Rise. University of New south Wales Water Research laboratory prepared for Gold Coast City Council.

Corbett, B. Tomlinson, R. \& Jackson, L.A., (2005). Reef Breakwaters for Coastal Protection: Safety Aspects and Tolerances. Proc. $17^{\text {th }}$ Australasian Coasts \& Ports Conference, Adelaide.

Jackson, L.A., Corbett, B., Tomlinson, R.B., McGrath, J.E. and Stuart, G., (2007), Narrowneck Reef: Review of Seven Years of Monitoring”, Shore and Beach, Vol. 75 Iss.4, pp. 67 - 79.

Jackson, L.A., Reichelt, R., Restall, S., Corbett, B., Tomlinson, R.B. and McGrath, J., (2005) "Marine Ecosystem Enhancement on Geotextile Coastal Protection Reef - Narrowneck Reef Case Study.”, Coastal Engineering 2004, Proc. $29^{\text {th }}$ Int. Conf. Coastal Engg., Lisbon. World Scientific, pp. 3940-3952.

Jackson, L.A., Tomlinson, R.B., Turner, I., Corbett, B., D’Agata, M. and McGrath, J., (2005) "Narrowneck Reef: Results of 4 years monitoring and modifications" $4^{\text {th }}$ Int Surfing Reef Symposium, Los Angeles, January 2005.

Jackson, L.A., Tomlinson, R.B., McGrath, J.E. and Turner, I., (2003) "Monitoring of a multi functional submerged geotextile reef breakwater, Gold Coast, Australia", Coastal Engineering 2002, Proc. $28^{\text {th }}$ Int. Conf. Coastal Engg., Cardiff, pp. 1923-1935.

Jackson, L.A., McGrath, J. and Tomlinson, R.B., (1997), "Strategy for Protection of the Northern Gold Coast Beaches", Proc. 13th Aust. Conf. Coastal Ocean Engrg., Christchurch, pp. 279-284, ISBN 0908993-15-3.

Splinter, K., Elliott-Smith, M., Lane, C. and Tomlinson, R., (2009). Coastal Imaging - Palm Beach and Northern Beaches, Gold Coast. May 2009 to October 2009. Griffith Centre for Coastal Management Research Report No. 97-02

Strauss, D., Murray, T., Volep, E., Lane, C. and Tomlinson, R., (2012). Coastal Imaging - Palm Beach and Northern Beaches, Gold Coast. November 2011 to April 2012. Griffith Centre for Coastal Management Research Report No 97.7

Tomlinson, R. B., Jackson, L.A. \& Corbett, B., (2007). Baseline Data Assessment Volume 5: Summary of Narrowneck Reef Monitoring to May 2007. GCCM Research Report No. 63. 